\title{
Research on the Evaluation Model of Electronic Commerce Innovation Ability of College Students Based on Analytic Hierarchy Process
}

\author{
LuoLang \\ Beijing University of Posts and Telecommunications \\ BUPT \\ Beijing, China \\ luolang0111@163.com
}

\author{
LiuYao, HuTao \\ Beijing University of Posts and Telecommunications \\ BUPT \\ Beijing, China
}

\begin{abstract}
To solve the problems of index establishment and reasonable quantification in the evaluation model of electronic commerce innovation ability of college students, this paper makes a careful analysis of the existing problems of evaluation system of the traditional education, puts forward a more comprehensive index evaluation system including innovative foundation, innovative thinking, innovative skills and innovative potential, and establishes the evaluation model of the multi-level analysis of electronic commerce innovation ability of college students, comprehensive evaluation; this paper gives a multi-dimensional analysis and comprehensive evaluation from different angles, which are tested by living examples, and provides a more systematic, comprehensive, feasible approach for the comprehensive evaluation of electronic commerce innovation ability of college students.
\end{abstract}

Keywords-electronic commerce; innovation ability; Analytic Hierarchy Process; evaluation model

\section{INTRODUCTION}

The evaluation of the traditional education mainly focuses on the students' examination results during the school, strengthens the role of examinations excessively, so that the evaluation form becomes rigid and single, and the contradiction of the employing units' demand for the talent innovation ability becomes more and more prominent. Therefore, colleges and universities should take the evaluation of innovative ability with examination results as a complementary evaluation standard, in order to reflect the changes of concepts of modern education and the social demand [1].

The commonly used methods of the comprehensive evaluation on the electronic commerce innovation ability of college students include comprehensive grading method, fuzzy comprehensive judgment method, and comprehensive evaluation theory based on extension theory[2]. Because AHP is a decision-making method of multiple criteria and targets combined with the qualitative and quantitative analysis, it breaks a complex decision-making problem down into a number of factors, and makes these factors form the hierarchical structure according to the dominance relationship, so as to get the weight of each factor through the comparison of every two factors of the importance of various factors on the same level in the hierarchy, then the decision-maker can make a comprehensive evaluation to be mathematical, and the evaluation has the features of strong system performance, wide application and simplicity prominence. In particular, it plays an important role in the qualitative judgment[3]. In view of this, this paper adopts the analytic hierarchy process to make a comprehensive evaluation of electronic commerce innovation ability of college students, and to provide a new idea and method for solving the similar problems.

\section{The ThOUght Method AND PROCEDURE OF AHP}

\section{A. The thought method and its production of AHP}

The Analytical Hierarchy Process, referred to as AHP, is a systematic and hierarchical analysis method combined with qualitative and quantitative methods, which was proposed by the USA operational research expert, Professor A. L. Seaty in the 1970's of the twentieth century. It is an analytical method of decision-making problems to deal with the complex social, political, economic and technological problems, especially with the decision-making of the multiple targets and multiple schemes. He organized the various factors which the complex system problem contained by means of defining the interrelated orderly hierarchies, and he also provided the quantitative description of the relative importance for the same hierarchical elements according to the qualitative judgment, and determined the relative importance weights of the elements of each hierarchy by using the mathematical method: finally, according to the numerical value and the weight of each index, make a comprehensive evaluation on the research questions.

\section{B. The basic procedure of $A H P$}

(1) The decision-making problem will be divided into several levels: the goal level, specific index level and criterion level. The bottom node is the specific index which influences the results, known as the "sub-index level"; the second level is "index class level", which will organize a number of related indexes as a class (or known as a subsystem) to be reflected on a larger category performance; the top level is "target level", which has only a node, and it indicates the final evaluation results. (2) Determine the weights of each criterion for the target weight and each solution for the criterion through the 
inter-comparison. These weights in the process of human thinking are often qualitative, while the quantitative method of the weights should be given in the analytic hierarchy process. (3) Carry out a comprehensive analysis of the solution level on the weight of the criterion level and of the criterion level on the weight of the target level, and determine the weight of the final solution level on the target level. In the practical application, adopting a definite evaluation method can figure out the evaluation value of the top index though the each refined index from the bottom level — namely the final evaluation results.

\section{THE ESTABLISHMENT OF EVALUATION INDEX SYSTEM}

Many factors affect the electronic commerce innovation abilities of college students, and some factors correlate with each other. In order to reflect the level of electronic commerce innovation ability of college students accurately, we need to construct an evaluation index system from various angles and levels. To determine the index composition of evaluation model of innovative ability of college students objectively, the author referred to a large number of documents based on[4][7], and followed the scientific, comprehensive and operational principles of the index system choice, through the questionnaire survey and interviews of the students, teachers and experts, and eventually established the evaluation index system of electronic commerce innovation ability of college students and the various evaluation criteria, see Table 1

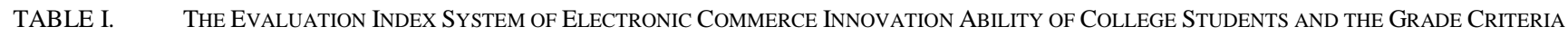

\begin{tabular}{|c|c|c|c|c|c|}
\hline \multirow{2}{*}{$\begin{array}{l}\text { First Grade } \\
\text { Index }\end{array}$} & \multirow[b]{2}{*}{ Second Grade Index } & \multicolumn{4}{|c|}{ Criteria of Evaluation Grade } \\
\hline & & Grade I (excellent) $(\geq 85)$ & Grade II (good) (70—85) & Grade III (average) (60-70) & Grade IV (poor) $(<60)$ \\
\hline \multirow{3}{*}{$\begin{array}{l}\text { Innovative } \\
\text { foundation }\end{array}$} & $\begin{array}{l}\text { Professional knowledge } \\
\text { and ability }\end{array}$ & Excellent scores $(\geq 85)$ & Good scores(70-85) & Average scores(60-70) & Poor scores $(<60)$ \\
\hline & $\begin{array}{l}\text { Information retrieval } \\
\text { ability }\end{array}$ & $\begin{array}{l}\text { Be able to retrieve the informatiol } \\
\text { needed comprehensively, } \\
\text { proficiently and quickly }\end{array}$ & $\begin{array}{l}\text { Be able to complete the require } \\
\text { information retrieval in } \\
\text { accordance with the } \\
\text { requirements }\end{array}$ & $\begin{array}{l}\text { Be able to complete the } \\
\text { required information } \\
\text { retrieval basically }\end{array}$ & $\begin{array}{l}\text { Retrieval ability is poor, } \\
\text { and be not able to } \\
\text { complete according to th } \\
\text { requirements }\end{array}$ \\
\hline & Cross knowledge ability & $\begin{array}{l}\text { Overall understanding of } \\
\text { Knowledge of relevant subjects, } \\
\text { and the mutual integration and } \\
\text { permeability of the subject }\end{array}$ & $\begin{array}{l}\text { A comprehensive understandin, } \\
\text { of the relevant subject } \\
\text { knowledge, and he can combin } \\
\text { the subject knowledge under th } \\
\text { guidance of teachers. }\end{array}$ & $\begin{array}{l}\text { The understanding of the } \\
\text { relevant subject knowledge } \\
\text { is ordinary. }\end{array}$ & $\begin{array}{l}\text { The relevant subject } \\
\text { knowledge is known littl }\end{array}$ \\
\hline \multirow[t]{4}{*}{$\begin{array}{l}\text { Innovation } \\
\text { thinking }\end{array}$} & Intuitive thinking ability & $\begin{array}{l}\text { Good at making judgments, } \\
\text { guessing and reasoning for new } \\
\text { things on the basis of perception }\end{array}$ & $\begin{array}{l}\text { Be able to make judgments, } \\
\text { guess and reason for new things } \\
\text { on the basis of perception }\end{array}$ & $\begin{array}{l}\text { Not be able to judge, guess } \\
\text { and reason on the basis of } \\
\text { perception. }\end{array}$ & $\begin{array}{l}\text { He is not sensitive to ney } \\
\text { things and does not care } \\
\text { about. }\end{array}$ \\
\hline & $\begin{array}{l}\text { Deductive reasoning } \\
\text { ability }\end{array}$ & $\begin{array}{l}\text { Be good at the abstract summary, } \\
\text { induction and deduction. }\end{array}$ & $\begin{array}{l}\text { Be able to make abstract } \\
\text { summary, induction and } \\
\text { deduction. }\end{array}$ & $\begin{array}{l}\text { Not be able to make abstray } \\
\text { summary, induction and } \\
\text { deduction generally. }\end{array}$ & $\begin{array}{l}\text { Not be able to make } \\
\text { abstract summary, } \\
\text { induction and deduction } \\
\text { basically. }\end{array}$ \\
\hline & Critical thinking ability & $\begin{array}{l}\text { Have the courage and be good at } \\
\text { thinking critically, and thinking } \\
\text { method is unique. }\end{array}$ & $\begin{array}{l}\text { Be able to criticize, and have hi } \\
\text { own views on the problem }\end{array}$ & $\begin{array}{l}\text { Call in question about the } \\
\text { problem }\end{array}$ & $\begin{array}{l}\text { Faithful to the textbook, } \\
\text { and have blind faith in } \\
\text { authorities }\end{array}$ \\
\hline & Creative thinking ability & $\begin{array}{l}\text { Active thinking, good at proposin } \\
\text { the model to break the } \\
\text { conventional problem solving }\end{array}$ & $\begin{array}{l}\text { Be able to propose the model to } \\
\text { break the conventional problem } \\
\text { solving }\end{array}$ & $\begin{array}{l}\text { Be able to put forward the } \\
\text { model to break the } \\
\text { conventional problem } \\
\text { solving under the guidance } \\
\text { of teachers }\end{array}$ & $\begin{array}{l}\text { Thinking is more rigid, } \\
\text { and stick in the mud }\end{array}$ \\
\hline \multirow[t]{3}{*}{$\begin{array}{l}\text { Innovation } \\
\text { skill }\end{array}$} & $\begin{array}{l}\text { The ability to find } \\
\text { problems }\end{array}$ & $\begin{array}{l}\text { Thinking is sensitive, and good at } \\
\text { discovering new problems }\end{array}$ & $\begin{array}{l}\text { Thinking is more sensitive, and } \\
\text { be able to find new problems }\end{array}$ & $\begin{array}{l}\text { Be able to find new } \\
\text { problems under the } \\
\text { guidance of teachers }\end{array}$ & $\begin{array}{l}\text { Thinking is not sensitive } \\
\text { basically not be able to } \\
\text { find new problems }\end{array}$ \\
\hline & $\begin{array}{l}\text { The ability to solve } \\
\text { problems }\end{array}$ & $\begin{array}{l}\text { Good at linking theory with } \\
\text { practice and solve the problem } \\
\text { creatively }\end{array}$ & $\begin{array}{l}\text { Be able to link theory with } \\
\text { practice and solve the problem } \\
\text { creatively }\end{array}$ & $\begin{array}{l}\text { Be able to solve the proble } \\
\text { creatively under the } \\
\text { guidance of teachers }\end{array}$ & $\begin{array}{l}\text { Basically not be able to } \\
\text { solve problems }\end{array}$ \\
\hline & $\begin{array}{l}\text { The ability to implement } \\
\text { programs }\end{array}$ & $\begin{array}{l}\text { Good at putting the theory schem } \\
\text { into practice }\end{array}$ & $\begin{array}{l}\text { Be able to put the theory schem } \\
\text { into practice }\end{array}$ & $\begin{array}{l}\text { Be able to put the theory } \\
\text { scheme into practice under } \\
\text { the guidance of teachers }\end{array}$ & $\begin{array}{l}\text { Basically not be able to } \\
\text { put the theory scheme in } \\
\text { practice }\end{array}$ \\
\hline \multirow[t]{2}{*}{$\begin{array}{l}\text { Innovation } \\
\text { potential }\end{array}$} & $\begin{array}{l}\text { The ability to express and } \\
\text { communicate }\end{array}$ & $\begin{array}{l}\text { Good at expressing, and having th } \\
\text { strong ability to communicate }\end{array}$ & $\begin{array}{l}\text { The ability of expression and } \\
\text { communication is strong. }\end{array}$ & $\begin{array}{l}\text { The ability of expression } \\
\text { and communication is } \\
\text { ordinary. }\end{array}$ & $\begin{array}{l}\text { The ability of expression } \\
\text { and communication is } \\
\text { poor }\end{array}$ \\
\hline & Innovative and will powe & $\begin{array}{l}\text { The willpower is tough, and the } \\
\text { innovative determination and } \\
\text { confidence is strong. }\end{array}$ & $\begin{array}{l}\text { The willpower is less tough, an } \\
\text { the innovative determination an } \\
\text { confidence is less strong. }\end{array}$ & $\begin{array}{l}\text { The willpower is less tough } \\
\text { and the innovative } \\
\text { determination and } \\
\text { confidence is ordinary. }\end{array}$ & $\begin{array}{l}\text { The willpower is not } \\
\text { tough. }\end{array}$ \\
\hline
\end{tabular}




\section{CONSTRUCtion OF THE EVAluation MOdEl BASED ON AHP}

\section{A. The hierarchical structure to form problems}

According to Table 1, establish the hierarchy structure chart of comprehensive evaluation of electronic commerce innovative ability of college students, as shown in Table 2.

TABLE II. THE HIERARCHY STRUCTURE OF COMPREHENSIVE EVALUATION OF ELECTRONIC COMMERCE INNOVATIVE ABILITY OF COLLEGE STUDENTS

\begin{tabular}{|c|c|c|}
\hline \multicolumn{3}{|c|}{$\begin{array}{l}\text { The hierarchy structure of comprehensive evaluation of electronic } \\
\text { commerce innovative ability of college students }\end{array}$} \\
\hline & First Grade Index & Second Grade Index \\
\hline \multirow{12}{*}{$\begin{array}{c}\text { A1:Innovative } \\
\text { Ability Evaluation }\end{array}$} & \multirow{3}{*}{$\begin{array}{l}\text { B1:Innovative } \\
\text { Foundation }\end{array}$} & $\begin{array}{l}\text { C1::Professional Knowledge } \\
\text { and Ability }\end{array}$ \\
\hline & & $\begin{array}{l}\text { C2:Information retrieval } \\
\text { Ability }\end{array}$ \\
\hline & & C3:Cross Knowledge Ability \\
\hline & \multirow{4}{*}{$\begin{array}{l}\text { B2:Innovative } \\
\text { Thinking }\end{array}$} & C4:Intuitive Thinking Ability \\
\hline & & $\begin{array}{l}\text { C5:Deductive Reasoning } \\
\text { Ability }\end{array}$ \\
\hline & & C6:Critical Thinking Ability \\
\hline & & C7:Creative Thinking Ability \\
\hline & \multirow{3}{*}{$\begin{array}{l}\text { B3:Innovative } \\
\text { Skill }\end{array}$} & $\begin{array}{l}\text { C8:The Ability to Find } \\
\text { Problem }\end{array}$ \\
\hline & & $\begin{array}{l}\text { C9:The Ability to Solve } \\
\text { Problem }\end{array}$ \\
\hline & & $\begin{array}{l}\text { C10:The Ability to Implement } \\
\text { Programs }\end{array}$ \\
\hline & \multirow{2}{*}{$\begin{array}{l}\text { B4:Innovative } \\
\text { Potential }\end{array}$} & $\begin{array}{l}\text { C11:The Ability to Implement } \\
\text { Program }\end{array}$ \\
\hline & & C12:Innovative and Will Power \\
\hline
\end{tabular}

\section{B. Construction of the judgment matrix}

In view of some factors on the above level, the relative importance of the factors on the same level in the hierarchical structure can be carried out by the comparison of every two factors. Suppose that the factor $A_{k}$ of Level A connects with $B_{1}, B_{2}, \cdots, B_{n}$ of the next level B , it can be constructed as the following judgment matrix:

$$
\mathrm{A}=\left(a_{i j}\right)_{n * m}=\left[\begin{array}{ccc}
a_{11} & a_{12} \ldots & a_{1 n} \\
a_{21} & a_{22} \ldots & a_{2 n} \\
\vdots & \vdots & \vdots \\
a_{n 1} & a_{n 2} \cdots & a_{n n}
\end{array}\right]
$$

In the formula (1):

$a_{i j}(i=1,2, \cdots, n ; j=1,2, \cdots n)$ can be expressed as the scale value of the relative importance for the factors $B_{i}$ and $B_{j}$ against $A_{k}$, and the valuation method adopts the scaling method of Saaty 9.

\section{The determination of the single sequence weight of each level}

Solve the maximum eigenvalue and eigenvector of the judgment matrix. The eigenvector represents the weight of various factors on the same level which influence some factors of the above level. Generally the simplified calculation is carried out by using the summation method or the square root method. This is calculated by using the square root method.

\section{Consistency test}

When the various factors of the complex event are compared by every two factors, the subjective judgment matrix obtained usually need to carry out the consistency check. When the consistency ratio is $\mathrm{CR}=\mathrm{CI} / \mathrm{R}<0.1$, the consistency of the matrix is considered to be acceptable, or it needs to revise the judgment matrix. Among them, CI is the consistency test index; $\mathrm{RI}$ is the average random consistency index.

\section{E. The determination of the total sequence weight of the level}

The calculation of level by level should be carried out orderly along the hierarchical structure from top to bottom, and then the coefficient of the relative importance of the bottom level factors relative to the target level can be obtained, namely weight $\omega_{i}$ of each evaluation index.

\section{F. Comprehensive sequence}

By using the weight $\omega_{i}$ of each evaluation index and the score $\mathrm{X}_{\mathrm{i}}$ of its corresponding index, the comprehensive score $\mathrm{S}$ of each evaluation index can be obtained, and the comprehensive evaluation of the testing samples can be carried on according to the size of S value.

$$
\begin{array}{r}
S=\sum_{i=1}^{n} X_{i} \omega_{i}{ }_{(2)} \\
\text { V. EXAMPLE ANALYSIS }
\end{array}
$$

\section{EXAMPLE ANALYSIS}

Now take the evaluation of electronic commerce innovation ability of a student as an example, and select the relevant experts, leaders and teachers of the university to make every two comparison of various evaluation indexes. The judgment matrix is constructed as follows:

The judgment matrix is $\mathrm{A}-\mathrm{B}$

$\left[\begin{array}{ccccc}A & B_{1} & B_{2} & B_{3} & B_{4} \\ B_{1} & 1 & 2 & 3 & 4 \\ B_{2} & 1 / 2 & 1 & 2 & 1 \\ B_{3} & 1 / 3 & 1 / 2 & 1 & 1 / 2 \\ B_{4} & 1 / 2 & 1 & 2 & 1\end{array}\right]$

The judgment matrix is $\mathrm{B}_{1}-\mathrm{C}$ 


$$
\left[\begin{array}{cccc}
B_{1} & C_{1} & C_{2} & C_{3} \\
C_{1} & 1 & 3 & 2 \\
C_{2} & 1 / 3 & 1 & 1 / 2 \\
C_{3} & 1 / 2 & 2 & 1
\end{array}\right]
$$

The judgment matrix is $\mathrm{B}_{2}-\mathrm{C}$

$\left[\begin{array}{ccccc}B_{2} & C_{4} & C_{5} & C_{6} & C_{7} \\ C_{4} & 1 & 1 & 1 / 2 & 1 \\ C_{5} & 1 & 1 & 2 & 1 \\ C_{6} & 2 & 1 / 2 & 1 & 1 / 2 \\ C_{7} & 1 & 1 & 2 & 1\end{array}\right]$

The judgment matrix is $\mathrm{B}_{3}-\mathrm{C}$

$\left[\begin{array}{cccc}B_{3} & C_{8} & C_{9} & C_{10} \\ C_{8} & 1 & 2 & 3 \\ C_{9} & 1 / 2 & 1 & 2 \\ C_{10} & 1 / 3 & 1 / 2 & 1\end{array}\right]$

The judgment matrix is $\mathrm{B}_{4}-\mathrm{C}$

$\left[\begin{array}{ccc}B_{4} & C_{11} & C_{12} \\ C_{11} & 1 & 1 / 3 \\ C_{12} & 3 & 1\end{array}\right]$

The weight vector of each evaluation index can be obtained according to the calculation of AHP steps, and the consistency of each judgment matrix can pass the test.

$$
\omega^{-1}=[0.2283,0.068,0.126,0.047,0.067,0.047,0.067,0.067,
$$
$0.036,0.020,0.057,0.170]$

The scores in each evaluation index of the student for the evaluation are marked by the guidance teachers, course teachers, counselors, student representatives, and the respective scores:

$$
x=\{82,75,90,75,85,82,78,86,79,72,78,90)
$$

By the formula (2), the student can get $S=83.253$, and the student's electronic commerce innovation ability is close to Grade I, which belongs to the grade II (good). In addition, judging from the weight vector $\omega$, the professional knowledge level, cross knowledge level and innovative will occupy an important position in the electronic commerce innovation ability evaluation. Therefore, we should strengthen the command of the students' professional knowledge in the process of teaching, broaden the students' knowledge and cultivate the students to possess the innovative confidence and perseverance.

\section{CONClusion}

1. The weight value of each index determined by the AHP and the comprehensive use of quantitative and qualitative evaluation methods can avoid the subjectivity in the evaluation process effectively and reflect the objective situation of the evaluation object relatively accurately. 2. Compared with other evaluation methods, this method preserves the good flexibility, so that different universities can determine the corresponding evaluation index system according to their actual conditions in order to improve the comprehensiveness of evaluation. 3. When the previous evaluation methods constructed an evaluation index system, it is difficult give reasonable weight values because there are many indexes and the degree of distinction is not high[8]. The Analytical Hierarchy Process can make up for this deficiency effectively. In short, among the evaluations of comprehensive qualities of the students, the Analytic Hierarchy Process will meet the requirements of comprehensiveness of evaluation indexes and the scientificity of the weight of each index in the evaluation process, and the comprehensive application of the quantitative and qualitative evaluation method will improve the accuracy and feasibility of the evaluation results.

\section{REFERENCES}

[1] QIAO Hai-shu, LI Yuan-hang. Review on the Study of the Cultivation of Innovative Ability of College Students [J]. Education Science of Universities, 2008(1): 11. 12.(In Chinese)

[2] MARSH D,WATERS F,MARSH T.Inventive Principles with Application in Education [J]. The TRIZ Journal,2004(4):1-17.

[3] YAn Li-ya. A Comparative Study of American " 4 H” Education and the Quality Education of College Students in our Country [A]. Education Information of the World, 2009. 03. P65-67. (In Chinese)

[4] ZHANG Yong-mei, JIN Yan-xia, DONG Yong-hua. Implementation of the Evaluation System of Innovative Ability of College Students [J]. Computer and Modernization, 2008, 149(1): 21-124. (In Chinese)

[5] ZHANG Xin, TAO Hua-ye, SUI Jin-xue. Research on the Comprehensive Evaluation of Innovative Ability of College Students Based on the Extension [J]. Higher Education Forum, 2010, 5(5): 45-48. (In Chinese)

[6] XU Hong. A study on the Evaluation Model of Innovative Ability of College Students Majoring in Computer Science Based on the Fuzzy Theory [J]. Computer Education, 2008, 14(5): 103-106. (In Chinese)

[7] TIAN Yong, ZHANG Yan, SONG Yu-Shan. A Study on the Evaluation Index System of Innovative Ability of Agricultural College Students [J]. Agricultural Science and Technology and Equipment, 2010, 190(4): 119-122. (In Chinese)

[8] Ma Wanmin. Research on the Evaluation Model of Quality of Talent cultivation of Higher Education [J]. China Soft Science, 2008(8): 153. 156. (In Chinese) 